\title{
Donald Trump, Media Spectacle, and Authoritarian Populism
}

\author{
Douglas Kellner
}

\section{In Remembrance of Ben Agger, an Honorable Critical Theorist}

Explaining the Donald Trump phenomenon is a challenge that will occupy critical theorists of U.S. politics for years to come. My first take on the Trump phenomenon is that Donald Trump won the Republican primary contest and then the 2016 U.S. Presidential Election because he is the master of media spectacle, a concept that I've been developing and applying to U.S. politics and media since the mid-1990s.[1] In this study, I will first discuss Trump's use of media spectacle in his business career, in his effort to become a celebrity and reality-TV superstar, and his political campaigns. Then I shall examine how Trump embodies Authoritarian Populism and has used racism, nationalism, xenophobia, and the disturbing underside of American politics to mobilize his supporters in his successful Republican primary campaign and in the hotly contested win in the 2016 general election.

\section{Donald Trump and the Politics of the Spectacle}

I first came up with the concept of media spectacle to describe the key phenomenon of US media and politics in the mid-1990s. This was the era of the O.J. Simpson murder case and trial, the Clinton sex scandals, and the rise of cable news networks like Fox, CNN, and MSNBC and the 24/7 news cycle that has dominated US politics and media since then.[2] The 1990s was also the period when the Internet and New Media took off so that anyone could be a political commentator, player, and participant in the spectacle, a phenomenon that accelerated as New Media morphed into Social Media and teenagers, celebrities, politicians, and others wanting to become part of the networked virtual world joined in.

The scope of the spectacle has thus increased in the past decades with the proliferation of new media and social networking like Facebook, YouTube, Twitter, Instangram, Skype, and the like that increases the scope and participation of the spectacle. By "media spectacles" I am referring to media constructs that present events which disrupt ordinary and habitual flows of information, and which become popular stories which capture the attention of the media and the public, and circulate through broadcasting networks, the Internet, social networking, smart phones, and other new media and communication technologies. In a global networked society, media spectacles proliferate instantaneously, become virtual and viral, and in some cases becomes tools of socio-political transformation, while other media spectacles become mere moments of media hype and tabloidized sensationalism.

Dramatic news and events are presented as media spectacles and dominate certain news cycles. Stories like the 9/11 terror attacks, Hurricane Katrina, Barack Obama and the 2008 U.S. presidential election, and in 2011 the Arab Uprisings, the Libyan revolution, the UK Riots, the Occupy movements and other major media spectacles of the era, cascaded through broadcasting, print, and digital media, seizing people's attention and emotions, and generating complex and multiple effects that may make 2011 as memorable a year in the history of social upheaval as 1968.[3]

In today's highly competitive media environment, "Breaking News!" of various sorts play out as media 
spectacle, including mega-events like wars, 9/11 and other spectacular terrorist attacks, extreme weather disasters, or, in Spring 2011, political insurrections and upheavals. These spectacles assume a narrative form and become focuses of attention during a specific temporal and historical period, that may only last a few days, or may come to dominate news and information for extended periods of time, as did the O.J. Simpson Trial and the Clinton sex/ impeachment scandal in the mid-1990s, the stolen election of 2000 in the Bush/Gore presidential campaign, or natural and other disasters that have significant destructive effects and political implications, such as Hurricane Katrina, the BP Deepwater Horizon Oil Spill, or the Fukushima-Daiichi nuclear catastrophe. Media spectacles can even become signature events of an entire epoch as were, arguably, the 9/11 terrorist attacks which inaugurated a historical period that I describe as Terror War.

I've argued since 2008 that the key to Barack Obama's success in two presidential elections was largely due to his becoming a master of media spectacle, blending politics and performance in carefully orchestrated media spectacles (Kellner 2009 and 2012). Previously, the model of the mastery of presidential spectacle was Ronald Reagan who everyday performed his presidency in a well-scripted and orchestrated daily spectacle. Reagan was trained as an actor and every night Ron and Nancy reportedly practiced his lines for the next day performance like they had done in their Hollywood days. Reagan breezed through the day scripted with a teleprompter and well-orchestrated media events, smiling frequently, and pausing to sound-bite the line of the day.[4]

In the 2016 election, obviously Donald Trump emerged as a major producer of media spectacle (see Kellner 2016). Trump has long been a celebrity and master of the spectacle with promotion of his buildings and casinos from the 1980s to the present, his reality-TV shows, self-promoting events, and now his presidential campaign and presidency. Hence, Trump was empowered and enabled to run for the presidency in part because media spectacle has become a major force in US politics, helping to determine elections, government, and more broadly the ethos and nature of our culture and political sphere, and Trump is a successful creator and manipulator of the spectacle.

I would also argue that in recent years U.S. wars have been orchestrated as media spectacle, recalling Bush Jr's 2003 Iraq shock and awe campaign for one example. Likewise, terrorism has been orchestrated as media spectacle since the $9 / 11$ attack that was the most spectacular and deadly attack on the US heartland in history. As we know too well, school and mass shootings which can be seen as a form of domestic terrorism, have become media spectacle with one taking place in 2015 in Virginia on live TV, while the stock market, weather, and every other form of life can become part of a media spectacle. Hence, it is no surprise that political campaigns are being running as media spectacles and that Knights of the Spectacle like Donald Trump played the spectacle to win the presidency, nor is it surprising that Trump is playing his role as president as King of the Spectacle.

Trump's biographies reveal that he was driven by a need to compete and win,[5] and entering the highly competitive real estate business in New York in the 1980s, Trump saw the need to use the media and publicity to promote his celebrity and image. It was a time of tabloid culture and media-driven celebrity and Trump even adopted a pseudonym "John Baron" to give the media gossip items that touted Trump's successes in businesses, with women, and as a rising man about town.[6]

Trump derives his language and behavior from a highly competitive and ruthless New York business culture and an appreciation of the importance of media and celebrity to succeed in a media-centric hypercapitalism. Hence, to discover the nature of Trump's “temperament," personality, and use of language, we should recall his reality-TV show The Apprentice which popularized him into a super celebrity and made the Donald a major public figure for a national audience. Indeed, Trump is the first reality-TV candidate who ran his campaign and presidency like a realityTV series, boasting during the most chaotic episodes in his campaign that his rallies were the most entertaining, and sending outrageous Tweets into the Twitter-sphere which then dominated the news cycle on the ever-proliferating mainstream media and social networking sites. Hence, Trump is the first celebrity candidate and now president whose use of the media and celebrity star power is his most potent weapon in his improbable and highly surreal campaign and presidency.[7]

\section{The Apprentice, Twitter and the Summer of Trump}

Since Trump's national celebrity derived in part from his role in the reality-TV series The Apprentice, $[8]$ we need to interrogate this popular TV spectacle to help explain the Trump phenomenon. The opening theme music "For the Love of Money", a 1973 R\&B song by The O'Jays, established the capitalist ethos of the competition for the 
winning contestant to get a job with the Trump organization, and obviously money is the key to Trump's business and celebrity success, although there is much controversy over Trump's wealth, and so far he has not released his tax returns to quell rumors that he isn't as rich as he claims, that he does not contribute as much to charity as he has stated, and that many years he pays little or no taxes.

In the original format of The Apprentice, several contestants formed teams to carry out a task dictated by Trump, and each "contest" resulted with a winner, followed by Trump barking "you're fired" to the loser. Curiously, some commentators believe in the 2012 presidential election that Barack Obama beat Mitt Romney handily because he early on characterized Romney as a billionaire who liked to fire people, which is ironic since this is Trump's signature personality trait in his business, reality-TV, and now political career, which has seen him fire two campaign managers and more advisors by August 2016 and fire his National Security Advisor, FBI Director, and others during his still young presidency.

The Apprentice premiered in January 2004, and after six seasons, a new format was introduced: The Celebrity Apprentice. The celebrity apprentice series generally followed the same premise as the original, but with celebrities as contestants participating to win money for their chosen charities, rather than winning a job opportunity with the Trump organization. There have been seven seasons of The Celebrity Apprentice since 2008, although NBC announced on June 29, 2015 that it was severing all business ties with Trump due to the latter's comments about Mexican immigrants, but has said its relationship with Mark Burnett and the show will continue, although low ratings with another celebrity/politician/show biz dude Arnold Schwarzennegger, and his public feud with the Donald, has raised questions about the show's future.

When NBC started negotiating with Trump concerning the reality TV-series in 2002, according to NBC producer Jeff Gaspin, the network was not sure that the New York-centric real estate mogul would have a national resonance and the initial concept envisaged different billionaires each season hiring an apprentice. The show immediately got good ratings and Trump became a popular TV figure as he brought the contestants into his board room in Trump Tower, appraised their performances, insulted those who did not do well, and fired the loser.[9]

The Apprentice's TV Producer Mark Burnett broke into national consciousness with his reality-TV show Survivor, a neo-Darwinian epic of alliances, backstabbing, and nastiness, which provides an allegory of how one succeeds in the dog-eat-dog business world in which Donald Trump has thrived, and spectacularly failed as many of the books about him document. Both Burnett and Trump share the neo-Darwinian (a)social ethos of 19th century ultracompetitive capitalism with some of Donald Trump's famous witticisms proclaiming:

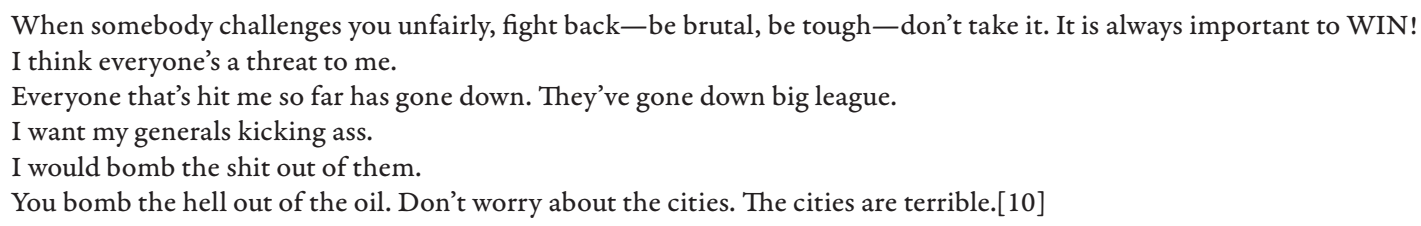

In any case, The Apprentice made Trump a national celebrity who became well-known enough to plausibly run for president. Throughout the campaign season Trump used his celebrity to gain media time. In addition to his campaign's ability to manipulate broadcast media, Trump is also a heavy user of Twitter and tweets throughout the day and night. Indeed, Trump may be the first major Twitter candidate and now president, and certainly he is the one using it most aggressively and frequently. Twitter was launched in 2006, but I don't recall it being used in a major way in the 2008 election, although Obama used Facebook and his campaign bragged that he had over a million "Friends" thus using Facebook as part of his daily campaign apparatus. I don't recall, however, previous Presidential candidates using Twitter in a big way like Donald Trump, although many had accounts.

Twitter is a perfect vehicle for Trump as you can use its 140-character framework for attack, bragging, and getting out simple messages or posts that engage receivers who feel they are in the know and involved in TrumpWorld when they get pinged and receive his tweets. When asked at an August 26, 2015, Iowa event as to why he uses Twitter so much, he replied that it was easy, it only took a couple of seconds, and that he could attack his media critics when he "wasn't treated fairly." Trump has also used Instagram --an online mobile photo-sharing, video-sharing and social networking service that enables its users to take pictures and videos, and share them on a variety of social networking platforms, such as Facebook, Twitter, Tumblr and Flickr.

Twitter is perfect for General Trump who can blast out his opinions and order his followers what to think. It enables Businessman and Politician Trump to define his brand and mobilize those who wish to consume or support 
it. Trump Twitter gratifies the need of Narcissist Trump to be noticed and recognized as a Master of Communication who can bind his warriors into an on-line community. Twitter enables the Pundit-in-Chief to opine, rant, attack, and proclaim on all and sundry subjects, and to subject TrumpWorld to the indoctrination of their Fearless Leader.

Hence, Trump is mastering new media as well as dominating television and old media through his orchestration of media events as spectacles and daily Twitter feeds. In Trump's presidential campaign kickoff speech on June 16, 2015, when he announced he was running for President, Trump and his wife Melania dramatically ascended down the stairway at Trump Towers, and the Donald strode up to a gaggle of microphones and dominated media attention for days with his drama. The opening speech of his campaign made a typically inflammatory remark that held in thrall news cycles for days when he stated: "The U.S. has become a dumping ground for everybody else's problems. [Applause] Thank you. It's true, and these are the best and the finest. When Mexico sends its people, they're not sending their best. They're not sending you. They're not sending you. They're sending people that have lots of problems, and they're bringing those problems with us. They're bringing drugs. They're bringing crime. They're rapists. And some, I assume, are good people."

This comment ignited a firestorm of controversy and a preview of Things to Come concerning vile racism, xenophobia, Islamophobia, and the other hallmarks of Trump's Cacophony of Hate. Debate over Trump's assault on undocumented immigrants would come to dominate daily news cycles of the Republican primaries and would continue to play out in the general election in Fall 2016. In the lead up to the first Republican primary debate in Fall 2015, Donald Trump got the majority of media time; his daily campaign appearances and the Republican primary debates became media spectacle dominated by Trump. Every day that Trump had a campaign event, the cable news networks would hype the event with crawlers on the bottom of the TV screen proclaiming "Waiting for Trump," with air-time on cable TV dominated by speculation on what he would talk about. Trump's speeches were usually broadcast live, often in their entirety, a boon of free TV time that no candidate of either party was awarded. After the Trump event, the rest of the day the pundits would dissect what he had said and his standing vis-à-vis the other Republican candidates. If Trump had no campaign event planned, he would fire off a round of Tweets against his opponents on his highly active Twitter account--which then would be featured on network cable news discussions as well as social media.

Hence, Trump's orchestration of media spectacle and a compliant mainstream media was a crucial factor in thrusting Trump ever further into the front runner status in the Republican primaries and winning for him the overwhelming amount of media attention and eventually the Republican nomination. The first major quantitative study indicated that from mid-June 2015 after Trump announced he was running through mid-July, Trump was in $46 \%$ of the news media coverage of the Republican field, based on Google news hits; he also got $60 \%$ of Google news searches, and I will bet that later academic studies will show how he dominated all media from newspapers to television to Twitter and new media to social networking during the Republican primaries and then during the general election.[11]

At a press conference on August 26, 2015, before his appearance at a rally in Dubuque Iowa, Trump bragged about how all three US cable news networks, as well as the other big three networks and even foreign news networks, were following him around all day, broadcasting all his live campaign appearances, and even his appearance for Jury duty in New York one day (he didn't have to serve and cable news anchors led off that night with ordinary people who had been waiting all day to see if they would be enrolled to serve on a jury who were asked what Trump had been doing all day, if he'd said anything, and so on, clearly a waste of news space and sign that Trump was dominating Republican primary coverage).

The August 26, 2015 Iowa event was the day that a Univision anchor Jorge Ramos tried to interrupt Trump's press conference to challenge Trump on immigration, in which Trump had his operatives throw Ramos out, but then let him in to create another media spectacle of Trump vs Ramos as they battled it out debating immigration, letting Trump dominate yet another news cycle.

The same day, Trump bragged about how one major media insider told him that it was the "Summer of Trump" and that it was amazing how he was completely dominating news coverage. Trump also explained, correctly I think, why he was getting all the media attention: "RATINGS," he explained, "it's ratings, the people love me, they want to see me, so they watch TV when I'm on." And I do think it is ratings that leads the profit-oriented television networks to almost exclusively follow Trump's events and give him live TV control of the audience. In his 1989 book, Fast Capitalism, and Speeding Up Fast Capitalism, a sequel to his earlier book, Ben Agger presented a framework for analyzing mutations in society, culture, and politics that have made possible a Donald Trump.[12] Without a media-saturated cybercapitalism, new technologies like Twitter and social networking, and a celebrity culture that has 
morphed into politics, there could never be a Donald Trump.

Trump rose to prominence in New York during the Reaganite ' $80 \mathrm{~s}$ as an embodiment of wild, entrepreneurial cowboy capitalism in an era of deregulation, the celebration of wealth, and the "greed is good" ethos of Wall Street, enabled by the Reagan administration. Trump's success was tied to an unrestrained finance capital that loaned him immense sums of money, often with minimal and problematic collateral, to carry through his construction projects. Trump was an extravagant consumer with a three-story penthouse at the top of Trump Towers, a 118 room mansion in Palm Beach, Florida Mar-A-Lago that he immediately opened for TV interview segments, and an obscene array of properties. He flaunted a yacht bought from Saudi arms dealer Adnan Khashoggi, and a personal airplane to jet-set him around the world to luxury resorts. Trump was featured on TV shows like Life Styles of the Rich and Famous, and his life-style was the subject of multi-page spreads in fashion and other popular magazines, making Trump the poster-boy for excessive "conspicuous consumption," of a degree that I doubt Veblen could have imagined.[13]

Trump's financial fortunes hit the economic slowdown that followed the Reagan orgy of unrestrained capitalism in the late 1980s, [14] and in the 1990s Trump almost became bankrupt. Fittingly, Trump had overinvested in the very epitome of consumer capitalism, buying a string of luxury gambling casinos in Atlantic City. The financial slump hit Trump's overextended casinos, driving him to put them on the market. The banks called in loans on his overextended real estate investments, and he was forced to sell off properties, his yacht, and other luxury items. Having temporarily lost his ability to borrow from finance capital to expand his real estate business, Trump was forced to go into partnerships in business ventures, and then sold the Trump name that was attached to an array of consumer items ranging from water to vodka, and men's clothes to fragrances.

Throughout his career, Trump has been particularly assiduous in branding the Trump name and selling himself as a businessman, a celebrity, presidential candidate, and president. Indeed, Trump's presidential campaign represents an obscene branding of a predatory hypercapitalist into a political candidate whose campaign and presidency has been run on bombast, dominating on a daily basis the mediascape, and gaining the attention of the public. Obviously, Trump is orchestrating political theater, his theatrics are sometimes entertaining, and sometimes utterly appalling. Hence, his candidacy represents another step in the merger between entertainment, celebrity and politics (here Ronald Reagan played a key role, our first actor President). Yet Trump is arguably the first major candidate to pursue politics as entertainment and thus to completely collapse the distinction between entertainment, news, and politics. $\mathrm{He}$ is also the first authoritarian populist to have been a party nominee for President in recent times.

\section{Donald Trump and Authoritarian Populism}

Much has been made of Donald Trump's character and whether he is fit to be president of the United States. In the following analysis, I want to suggest that the theories of Erich Fromm and his fellow German-Jewish refugees known as the "Frankfurt School" provide an analysis of authoritarian populism that helps explicate Trump's character, his appeal to his followers, and in general the Trump phenomenon.[15]

Erich Fromm was a German Jewish intellectual and psychoanalyst who was affiliated with the Frankfurt School, a group of German Jews and progressives who left Hitler's Germany in the early 1930s and settled in the United States, developing critical theories of fascism, contemporary capitalism, and Soviet Marxism from a theoretical standpoint that combines Marx, Freud, Weber, Nietzsche and other radical theorists and critics of Western civilization.[16] Fromm was the group's Freud expert who was affiliated with the Frankfurt Psychoanalytic Institute in Germany, and was a practicing analyst in Germany and then the United States. After breaking with the Frankfurt school in the late1930s, Fromm went on to becoming a best-selling author and radical social critic in the United States.

Fromm was a strong critic of Hitler and German fascism and I believe that his major books and some key ideas help explain the character, presidential campaign, and supporters of Donald Trump. Hence, in this discussion, I develop a Frommian analysis of Trump and his followers and take on the issue of how American authoritarian populism looks in the Era of Trump. This project begins with Fromm's Escape from Freedom, which explains how in modernity individuals submitted to oppressive and irrational regimes and in particular how Germans submitted to Hitler and fascism.[17] Escape combines historical, economic, political, ideological and socio-psychological analysis, as is typical of the best multidimensional work of Fromm and the Frankfurt School, and provides a model that we can apply to analyzing Trump and our current political situation.

Certainly, Trump is not Hitler and his followers are not technically fascists,[18] although I believe that we can 
use the terms authoritarian populism or neo-fascism to explain Trump and his supporters.[19] Authoritarian movements ranging from German and Italian fascism to Franco's Spain to Latin American and other dictatorships throughout the world center on an authoritarian leader and followers who submit to their leadership and demands. I maintain that Donald Trump is an authoritarian leader who has mobilized an authoritarian populist movement that follows his leadership. Arguably, Trump is an authoritarian populist in the traditions of Ronald Reagan and Margaret Thatcher. Like Reagan, Trump comes out of the entertainment industry and was a popular celebrity as he announced his candidacy in summer 2015 thanks in part to his television celebrity as every mainstream media outlet touted his announcing his candidacy. Trump does not share the conservative ideology of Reagan and Thatcher, although he shares their electoral strategy of taking a populist pose claiming to represent the people against the political establishment.

Yet Trump lacks Reagan's disciplined skills as a performer and Thatcher "Iron Lady" self-discipline and political rationality. Instead, Trump shoots from the lip and cannot resist insults, attacks, impolitic language and rants against those who dare to criticize or offend him. While Trump does not have a party apparatus or ideology like the Nazis, parallels to Nazism appeared clear to me watching a TV broadcast on August 21, 2015, of Trump's mega-rally in Mobile, Alabama. I watched all afternoon as the cable news networks broadcast nothing but Trump, hyping up his visit to a stadium where he was expecting 30-40,000 spectators, the biggest rally of the season. Although only 20some thousand showed up, which was still a "huge" event in the heat of summer before the primaries had even begun in earnest, Trump's flight into Alabama on his own Trump Jet and his rapturous reception by his admirers became the main story of the news cycle, as did many such daily events in what the media called "the summer of Trump."

What I focused on in watching the TV footage of the event was how the networks began showing repeated images of Trump flying his airplane over and around the stadium before landing and then cut away to big images of the Trump Jet every few minutes. This media spectacle reminded me of one of the most powerful propaganda films of all time - Leni Riefenstahl's Triumph of the Will $\neg-$ a German Nazi propaganda film of 1935. Triumph focuses on Hitler flying in an airplane through the clouds, looking out the window at the crowds below, landing, and driving through mass crowds applauding him as his proceeded through the streets of Nuremburg for a mass rally. The crowds along the way and in the stadium greeted Hitler with rapture as he entered the spectacle of a highly touted and orchestrated Nuremburg mass Nazi rally that Riefenstahl captured on film.

I do not know if the Trump operatives planned this parallel, or if it was just a coincidence, but it is clear that Trump, like Hitler, has organized a fervent mass movement outside of the conventional political party apparatuses. The anger and rage that Fromm attributed to Nazi masses in Escape from Freedom is also exhibited in Trump's followers as is the idolatry toward their Fuhrer, who arguably see Trump as the magic helper who will solve their problems by building a giant wall to keep out the threatening Other, a Fairy Tale scenario that Fromm would have loved to deconstruct.[20]

Like followers of European fascism in the 1930s, Trump's supporters over the years have suffered economic deprivation, political alienation, humiliation, and a variety of hard times, and they appear to be looking for a political savior to help them out with their problems and to address their grievances. Trump proposes magical solutions like a wall along the Mexican border that will keep out swarms of immigrants that he claims are taking away jobs in the U.S., as well as committing waves of crime. Trump claims he will create millions of "great" jobs without giving specific plans -- a claim refuted by his problematic business record that includes many bankruptcies, hiring of foreign workers to toil on his projects, some of whom he does not pay, and failures to pay many subcontractors who worked on his projects.[21]

Trump thus presents himself as a Superhero who will magically restore the U.S. to greatness, provide jobs and create incredible wealth, and restore the U.S. to its rightful place as the world's Superpower. In this Fairy Tale, the billionaire King will fight and destroy all the Nation's domestic and foreign enemies and the Superman will triumph and provide a Happy Ending for the people of the U.S.[22]

While Trump plays the role of the Übermensch (Superman or Higher Man) celebrated by the Nazis and embodies their Führerprinzip (leadership principle), Trump is a very American form of the Superhero, and lacks the party apparatus, advanced military forces, and disciplined cadres that the Nazis used to seize and hold power. Like other rightwing American populists, Trump bashed the Federal Reserve, the U.S. monetary system, Wall Street hedge fund billionaires, and neoliberal globalization, in the same fashion as Hitler attacked German monopoly capitalism. While Hitler ranted against monopoly capitalists, at the same time he accepted big donations from German industrialists, as brilliantly illustrated in the famous graphic by John Heartfield "the meaning of the Hitler 
salute" which showed Hitler with his hand up in the Nazi salute, getting bags of money from German capitalists. [23] Just as Hitler denounced allegedly corrupt and weak party politicians in the Weimar Republic, Trump decries all politicians as "idiots," "stupid," or "weak" - some of the would-be strongman's favorite words. In fact, Trump even attacked lobbyists, and claimed he alone was above being corrupted by money, since he was self-financing his own campaign. Of course, these claims were not really true and Trump filled his administration with lobbyists, corporate and political insiders, and other Swamp Creatures as he assembled his administration (see Kellner 2017).[24]

Trump has his roots in an American form of populism that harkens back to figures like Andrew Jackson, Huey Long, George Wallace, Pat Buchanan and, of course, the American carnival barker and snake oil salesman.[25] Like these classical American demagogues, Trump plays on the fears, grievances, and anger of people who feel that they have been left behind by the elites. Like his authoritarian populist predecessors, Trump also scapegoats targets from Wall Street to a feared mass of immigrants allegedly crossing the Mexican border and pouring into the States, overwhelming and outnumbering a declining White population.[26]

Trump's followers share antecedents in the Know Nothing movement of the 1850s, the Ku Klux Klan movement which achieved popularity and media in the 1920s, with Donald's father Fred Trump arrested at one of its rallies,[27] and the movement that made George Wallace a popular candidate in the 1960s. Like the alienated and angry followers of authoritarian populist movements throughout the world, Trump's admirers had suffered under the vicissitudes of capitalism, globalization, and technological revolution. For decades, they have watched their jobs being moved overseas, displaced by technological innovation, or lost through unequal economic development amid increasing divisions between rich and poor. With the global economic crisis of 2007-08, many people lost jobs, housings, savings, and suffered through a slow recovery under the Obama administration. The fact that Obama was the first black president further outraged many who had their racism and prejudices inflamed by eight years of attacks on Obama and the Obama administration by rightwing media and the Republican Party.

Indeed, Donald Trump was one of the most assiduous promoters of the "birther" myth, erroneously claiming that Barack Obama was born in Africa and was thus not eligible to serve as President of the United States. [28] In the 2008 presidential election, Trump made a big show of insisting that Obama show his birth certificate to prove he was born in the U.S., and although the Obama campaign provided photocopies of the original birth certificate in Hawaii and notices of his birth in Honolulu newspapers at the time, Trump kept insisting they were frauds and many of his followers continue to this day to believe the myth that Obama was not born in the USA.[29]

Yet unlike classic dictators who are highly disciplined with a fixed ideology and party apparatus, Trump is chaotic and undisciplined, viciously attacking whoever dares criticize him in his daily Twitter feed or speeches, thus dominating the daily news cycles with his outrageous attacks on Mexicans, Muslims, and immigrants, or politicians of both parties who dare to criticize him. Trump effectively used the broadcast media and social media to play the powerful demagogue who preys on his followers' rage, alienation, and fears. Indeed, by March 2016, media companies estimated that Trump received far more media coverage than his Republican Party contenders, and by June MarketWatch estimated that he had received \$3 billion worth of free media coverage.[30] Yet, at his whim, Trump bans news media from his rallies, including The Washington Post, if they publish criticisms that he does not like.

Like followers of European fascism, the Trump's authoritarian populist supporters are driven by rage: they are really angry at the political establishment and system, the media, and economic and other elites. They are eager to support an anti-establishment candidate who claims to be an outsider (which is only partly true as Trump has been a member of the capitalist real estate industry for decades, following his father, and has other businesses as well, many of which have failed).[31] Trump provokes their rage with classic authoritarian propaganda techniques like the Big Lie, when he repeats over and over that immigrants are pouring across the border and committing crime, that all his primary opponents, the media, and Hillary Clinton are "big liars," and that he, Donald Trump is the only one telling the truth—clearly the biggest lie of all.[32]

Trump's anti-immigrant and racist rhetoric, his Islamophobia, and his xenophobic nationalism plays into a violent racist tradition in the U.S. and activates atavistic fears of other races and anger among his white followers. Like European fascism, Trump draws on restorative nostalgia and promises to "Make America Great Again." Thus, to mobilize his followers, Trump arguably manipulates racism and nationalism and plays to the vile side of the American psyche and the long tradition of nationalism, America First-ism, and xenophobia, wanting to keep minorities and people of color outside of the country and "in their place."

Gun rights fanatics were one of Trump's strong core constituencies and never had a candidate (who previously 
had no visible connection to gun culture) so rabidly defended gun rights and attacked Clinton and Democrats who were allegedly dead-set on taking guns away from men who had little else to cling to.[33] Trump also played on the fears, grievances, and resentments of evangelicals who feared that in a secular culture their religious rights would be curtailed,[34] and nationalists who believed the nation was in decline and resented as well liberals who allegedly pushed civil rights agendas that favored people of color.

An article in The New Yorker by Evan Osmos describes Trump's followers as "The Fearful and the Frustrated" with the subtitle: "Donald Trump's nationalist coalition takes shape - for now." [35] The reporter had been following Trump's campaign and interviewing his followers and the article reveals that Trump has not only attracted Tea Party followers, but also white nationalists with journals like The Daily Stormer "who urged white men to "vote for the first time in our lives for the one man who actually reps our interests." Osmos interviews all over the country other members of far right neo-Nazi, white supremacist, and ultra nationalist groups and concludes:

From the pantheon of great demagogues, Trump has plucked some best practices -- William Jennings Bryan's bombast, Huey Long's wit, Father Charles Coughlin's mastery of the airwaves-but historians are at pains to find the perfect analogue, because so much of Trump's recipe is specific to the present. Celebrities had little place in U.S. politics until the 1920 Presidential election, when Al Jolson and other stars from the fledgling film industry endorsed Warren Harding. Two decades ago, Americans were less focused on paid-for politicians, so Ross Perot, a self-funded billionaire candidate, did not derive the same benefit as Trump from the perception of independence.[36]

Like fascists and authoritarian populists, Trump thus presents himself as the Superhero leader who can step from outside and solve the problems that Washington and politicians have created. In the form of authoritarian idolatry described by Fromm,[37] his followers appear to believe that Trump alone can stop the decline of the United States and make it "great" again. Over and over, Trump supporters claim that he is the only one who talks about issues like immigration, problems with Washington and politics, and the role of money in politics. Trump promotes himself as the tough guy who can stand up to the Russians and Chinese, and to "America's enemies." In the Republican primaries, he presented himself as "the most militarist" guy in the field and promised to build up the US military, and to utterly destroy ISIS and America's enemies, restoring the U.S. to its superpower status, which he says was lost by the Obama administration. Trump embodies the figure to excess of strong masculinity that Jackson Katz describes as a key motif in recent U.S. presidential elections. [38] With his bragging, chest-pounding, and hypermacho posturing, Trump provides a promise of restoration of White Male Power and authority that will restore America to its' greatness.

Macho Superman Trump will make "America Great Again" and vanquish all its enemies. Indeed, "Make America Great Again" is perhaps the defining motif of Trump's presidential campaign and presidency- - a slogan he put on his baseball caps that he handed out or sold to his supporters. The baseball hat makes it appear that Trump is an ordinary fellow, and links him to his followers as one of them, a clever self-presentation for an American authoritarian populist. Sporting a baseball cap on the campaign trail is especially ironic, given that Trump appears to have borrowed this fashion from award-winning, progressive documentary filmmaker Michael Moore who is perhaps the anti-Trump in the U.S. political imaginary. Further, in his speech at the Republican convention, this shouting red-faced, orange-haired demagogue presented himself as the "voice of the forgotten men and women" - a Depression era phrase of the Roosevelt administration which Trump inflects toward his white constituency who believes they have been forgotten and passed over in favor of the rich, minorities, and celebrities. In his daily tweets and speeches on the campaign trail, Trump used the discourse of national crisis also deployed by classic fascist and authoritarian regimes to describe the situation in the U.S. and the need for a savior to solve all the problems. In contrast to the Nazis, however, Trump tells his followers that it's his deal-making skills as a supercapitalist billionaire which credentials him to be the President, and he induces his followers to believe he will make a "great deal" for them and "Make America Great Again."

The slogan "Make America Great Again" refers for some of Trump's supporters to a time where White Males ruled and women, people of color, and others knew their place. It was a time of militarism where U.S. military power was believed to position America as the ruler of the world—although as the ambiguous Cold War and U.S. military defeats in Vietnam and the uncontrollable spaces of Iraq and Afghanistan, this era of American greatness was largely a myth. Yet the slogan is vague enough that Trump's followers can create a fantasy of a "great" past and dream that Trump will resurrect it - a fantasy conceit nourished by many authoritarian leaders in the 20th century.

Trump is replicating this phenomenon of authoritarian populism and his campaign exhibits in many ways the submission to the leader and the cause found in classic authoritarian movements. Yet Trump is also the embodiment 
of trends toward celebrity politics and the implosion of politics and entertainment which is becoming an increasingly important feature of U.S. politics (see Note 6). Further, Trump is a master of PR and promoting his image, and would even call up journalists pretending to be a PR agent to get gossip items planted about him in newspapers (see Note 5). More disturbing is the oft-played footage of Trump mimicking a New York Times reporter with a disability. [39] Indeed, there is a sinister side to Trump as well as the cartoonish and creepy side.

Trump is thus an authoritarian populist and his campaign replicates in some ways the submission to the leader and the cause found in classic authoritarian movements. In some ways, however, it is Mussolini, rather than Hitler, who Trump most resembles. Hitler was deadly serious, restrained, and repressed, while Trump is comical, completely unrestrained, and arguably unhinged.[40] Curiously, on February 28, 2016, Trump used his Twitter feed to post a quote attributed to Mussolini, which compared the Italian dictator to Trump, and in an interview on NBC's "Meet the Press" that morning said: "It's a very good quote," apparently not bothered by being associated with Mussolini. [41] There were also news clips that showed Trump speaking, chin jutting out in Mussolini-like fashion, and making faces and performing gestures that seemed to mimic characteristics associated with Mussolini.[42]

Like Mussolini, Trump has a buffoonish side which his mobocracy finds entertaining, but which turns off more serious folks. Trump is the embodiment of trends toward celebrity politics and the implosion of politics and entertainment which is becoming an increasingly important feature of U.S. politics. [43] Further, Trump is a master of PR and continues into his presidency to promote his image, the Trump organization, and the interests of his family businesses. Indeed, there is a disturbing side to Trump, and in the conclusion I will discuss how his uncontrollable ego, hyperauthoritarian tendencies, and need to create endless media spectacles and dominate the news may lead to the destruction of his presidency.

\section{Conclusion}

On May 9, 2017, Trump fired FBI Director James Comey creating the most stunning and perhaps consequential media spectacle of his presidency. There is a dialectic of the spectacle whereby those who lie by and prosper through the spectacle may undergo their downfall and destruction through media spectacles of scandal and delegitimation. Miraculously, Bill Clinton survived the spectacle of the Monica Lewinsky sex scandal and impeachment perhaps because the spectacle of the noxious Grand Inquisitor Ken Starr and a blood-thirsty Republican Congress turned public opinion to support Clinton despite his failings. Michael Jackson, by contrast, during the same era, had his career destroyed by revelations that he invited young boys to his home and bed for sleepovers. Yet after his death, Jackson underwent a miraculous resurrection of the spectacle as millions around the world mourned his death and gave his career and work an afterlife.

Trump's firing of Comey, however, has generated negative media spectacles highlighting his pathological mendacity as he claimed that he fired Comey because of the mishandling of Hillary Clinton's email problems during the 2016 presidential election. Few outside of Trump supporters believed this, however, especially after it was revealed that Comey had requested more resources to investigate the connections between the Trump organization and campaign and the Russians during the 2016 presidential election when there was strong evidence that the Russians had hacked the democrats and released embarrassing, or distracting, emails from the Clinton campaign to the press with the aid of Wikileaks (see Nance 2016 and Kellner 2017). Trump had long called the investigation a hoax and "fake news" but the very fact of firing Comey suggested that he was deeply worried about the investigation and was viciously struggling for his survival. Firing Comey, however, could lead to Trump's downfall as shortly thereafter, Special Counsel Robert S. Mueller was appointed to investigate the Trump-Russia connections and related issues.

No doubt, the many investigations into the Trump-Russia connections will be a major media spectacle of the contemporary era and perhaps one of the most momentous spectacles in U.S. history. U.S. politics are now totally bound up with the logic and dynamic of media spectacle and the fate of the nation demands on how the TrumpRussia spectacle unfolds and plays out. 


\section{Endnotes}

1. On my concept of media spectacle, see Kellner 2001; 2003a, 2003b, 2005, 2008, 2012, 2016, and 2017. This article draws upon and updates my two Trump books Kellner 2016 and 2017.

2. I provide accounts of the O.J. Simpson Trial and the Clinton sex/impeachment scandal in the mid-1990s in Kellner 2003b, ; engage the stolen election of 2000 in the Bush/Gore presidential campaign in Kellner 200; and describe the $9 / 11$ terrorist attacks and their aftermath in Kellner 2003a.

\section{See Kellner 2012.}

4. On the scripting of the Reagan presidency, see Cameron 1982.

5. See Michael D’Antonio, Never Enough. Donald Trump and the Pursuit of Success (New York: Thomas Dunne Books, 2015); Gwenda Blair, The Trumps (New York: Simon and Schuster, 2000); and Michael Kranish and Marc Fisher, Trump Revealed. An American Journey of Ambition, Ego, Money and Power. New York: Scribner, 2016 . Blair's chapter on "Born to Compete," op. cit., pp. 223ff., documents Trump's competitiveness and drive for success at an early age.

6. Marc Fisher, Will Hobson, "Donald Trump 'pretends to be his own spokesman to boast about himself.' Some reporters found the calls disturbing or even creepy; others thought they were just examples of Trump being playful." The Independent, May 13, 2016 at http://www. independent.co.uk/news/world/americas/us-elections/ donald-trump-pretends-to-be-his-own-spokesman-toboast-about-himself-a7027991.html (accessed August 9, 2016).

7. For my take on celebrity politics and the implosion of entertainment and politics in U.S. society, see Kellner, in Marshall and Redmond, pp. 114-134. See also Wheeler, 2013. The best study of Trump, the media, and his long cultivation and exploitation of celebrity is found in. O'Brien 2016 [2005].

8. Trump's book The Art of the Deal, co-written with Tony Schwartz (New York: Ballantine Books, 2005 [1987]), helped introduce him to a national audience and is a key source of the Trump mythology; see Blair, op. cit., $380 \mathrm{ff}$.

9. Gaspin was quoted in CNN, All Business. The Essential Donald Trump. September 5, 2016.

10. Quotations from Chairman Trump, edited by Carol Pogash. New York: Rosetta Books, 2016, pp 30, 152, 153.

11. Ravi Somaiya, "Trump's Wealth and Early Poll Numbers Complicate News Media's Coverage Decisions." The New York Times, July 24, 2015 at http:// www.nytimes.com/2015/07/25/business/media/ donald-trumps-wealth-and-poll-numbers-complicatenews-medias-coverage.html (accessed July 22, 2016).

12. Ben Agger, Fast Capitalism (Champaign-Urbana: University of Illinois Press, 1989) and Speeding Up Fast Capitalism (New York and London: Routledge, 2015).

13. Thorstein Veblen, Theory of the Leisure Class: An Economic Study in the Evolution of Institutions . New York: Dover, 1994 (1899).

14. For the story of Trump's financial down-fall and near collapse in the 1980s and 1990s, see the detailed and well-documented narratives in Barrett, op. cit.; John O'Donnell and James Rutherford, Trumped!: The Inside Story of the Real Donald Trump-His Cunning Rise and Spectacular Fall . New York: Simon and Schuster, 1991;D’Antonio,op. cit; andKranish and Fisher, op. cit.

15. The analysis of Fromm and Trump was first presented as "Fromm and the Counterrevolutionary Character: Frommian Reflections on Donald Trump" in a conference "The (in)sane society: Remembering Erich Fromm and the Frankfurt School," CUNY, New York, April 1, 2016

16. On Fromm, see Daniel Burston, The Legacy of Erich Fromm. Cambridge, Mass: Harvard University Press, 1991; Rainer Funk, Erich Fromm: His Life and Ideas. Translators Ian Portman, Manuela Kunkel. New York: Continuum International Publishing Group, 2003; Lawrence J. Friedman, The Lives of Erich Fromm: Love's Prophet . New York: Columbia University Press, 2013.

17. Erich Fromm, Escape from Freedom. New York: Holt Paperbacks, 1991 (1941).

18. Parenthetically, there were enough media comparisons between Trump and Hitler and fascism for Trump to say with some perhaps genuine perplexity "I'm not Hitler! I don't like the guy!" See Sam Sanders, “Trump Champions The 'Silent Majority, But What Does That Mean In 2016?" NPR, January 22, 2016 at http://www.npr.org/2016/01/22/463884201/trumpchampions-the-silent-majority-but-what-does-thatmean-in-2016 (accessed on July 20, 2016). At this time, Trump was asking his followers to raise their hands if they would vote for him as President, and the simultaneous raised hands going up looked like a mob of Hitler salutes! And there is a story out there that Trump keeps a book of Hitler's writings by his bedside; see O'Brien, op. cit., p. 200; the story originates from a UPI report, August 9, 1990, cited in O'Brien, op. cit., p. 260.

19. Carl Bernstein started calling Trump a neo-fascist and an American-brand fascist on CNN on June 19, 
2016. See Tom Boggioni, “Carl Bernstein: Donald Trump is a 'pathological liar' and America's first 'neofascist' nominee," Rawstory, June 19, 2016 at http://www. rawstory.com/2016/06/carl-bernstein-donald-trumpis-a-pathological-liar-and-americas-first-neofascistnominee/ (accessed on July 20, 2016). In an article by Adam Gopnik, "Being Honest About Trump, The New Yorker, July 14, 2016 at http://www.newyorker. com/news/daily-comment/being-honest-about-trump (accessed on July 20, 2016), Gopnik comments: "It is the essence of fascism to have no single fixed forman attenuated form of nationalism in its basic nature, it naturally takes on the colors and practices of each nation it infects. In Italy, it is bombastic and neoclassical in form; in Spain, Catholic and religious; in Germany, violent and romantic. It took forms still crazier and more feverishly sinister, if one can imagine, in Romania, whereas under Oswald Mosley, in England, its manner was predictably paternalistic and aristocratic. It is no surprise that the American face of fascism would take on the forms of celebrity television and the casino greeter's come-on, since that is as much our symbolic scene as nostalgic re-creations of Roman splendors once were Italy's." Op. cit.

20. The notion of "the magic helper" to whom the follower submits in the hopes their problems will be solved is found in Erich Fromm's Escape from Freedom , op. cit., pp. 174-178; on "authoritarian idolatry," see Sane Society, op. cit. p. 237f. Escape from Freedom not only critiqued Nazi ideology, the party apparatus, the concept of the Fuhrer, and the psychology of Nazi mass followers of Hitler in Escape from Freedom, but was also fascinated by fairy tales and magical thinking in National Socialism, a theme he expanded in later writings like The Forgotten Language: An Introduction to the Understanding of Dreams, Fairy Tales and Myths . New York: Random House, 1988.

21. On Trump's business failures, see Wayne Barrett, Trump: The Greatest Show on Earth: The Deals, the Downfall, the Reinvention . New York: Regan Books, 2016 (revision of 1992 book Trump: The Deals and the Downfall ); O’Brien, op. cit.; D'Antonio, op. cit.; David Cay Johnston, The Making of Donald Trump. New York: Melville House ; and Kranish and Fisher, Trump Revealed, op. cit. See also and "The Art of the Bad Deal. Donald Trump's Business Flops, Explained," Newsweek, August 8, 2018: 24-33,

22. On the centrality of the role of a Superhero in U.S. culture and politics, see Robert Jewett and John Lawrence, The American Monomyth. New York: Anchor, 1977 and Robert Jewett and John Lawrence, The Myth of the American Superhero. Grand Rapids, Mich: Wm. B. Eerdmans Publishing Company, 2002. Trump's campaign follows this model of the redemptive Hero who will slay America's enemies and return the Kingdom to peace and prosperity.

23. See the Heartfield images at https://www.google. $\mathrm{com} /$ search? $\mathrm{q}=$ John + Heartfield: + the + meaning+of + the + Hitler + salute $\&$ biw $=1600 \& b i h=1028 \& \mathrm{tbm}=\mathrm{isch}$
$\& \mathrm{tbo}=\mathrm{u} \&$ source $=$ univ $\& \mathrm{sa}=\mathrm{X} \& \mathrm{ved}=0 \mathrm{ahUKEw}$ jt $4 \mathrm{~K}$ vV-N7LAhVM6WMKHUPABGMQsAQIJg (accessed March 22, 2016).

24. After bragging how his campaign was self-funded during the Republican primaries, Trump released a statement showing that much of the money he spent was paid into his own companies; see Nicholas Confessore and Sarah Cohen, "Donald Trump's Campaign, Billed as Self-Funded, Risks Little of His Fortune." The New York Times, February, 5, 2016 at http://www. nytimes.com/2016/02/06/us/politics/donald-trumpscampaign-billed-as-self-funded-risks-little-of-hisfortune.html?_r=0 (accessed July 29, 2016). During the Fall Presidential election, Trump is forced to court donors and raise funds, thus undercutting his claims to be the only self-financing candidate.

25. See Lauren Langman and George Lundskow, "Escape From Modernity: Authoritarianism and the Quest for the Golden Age," Paper delivered at "The Psychodynamics of Self \& Society," Eighth Annual ASA Mini-Conference, Seattle, August 18, 2016.

26. Trump's vision of Latin American immigrants pouring over the border into the U.S. is a fantasy, as studies have shown that more Mexicans are returning to Mexico after working in the U.S. than coming into the country, illegal or not; see A na GonzalezBarrera, "More Mexicans Leaving Than Coming to the U.S. Net Loss of 140,000 from 2009 to 2014; Family Reunification Top Reason for Return." November 19, 2015 at http://www.pewhispanic.org/2015/11/19/ more-mexicans-leaving-than-coming-to-the-u-s/ (accessed September 3, 2016).

27. Kranish and Fisher, op. cit., pp. 27-28. It was not clear from police and media reports whether Fred Trump was marching with the Klan or was just part of the crowd that got involved in a melee with the police.

28. On the birther myth, see Michael D'Antonio op. cit, pp. 283ff.

29. Public Policy Polling reports that a "new poll finds that Trump is benefiting from a GOP electorate that thinks Barack Obama is a Muslim and was born in another country, and that immigrant children should be deported. 66\% of Trump's supporters believe that Obama is a Muslim to just $12 \%$ that grant he's a Christian. $61 \%$ think Obama was not born in the United States to only $21 \%$ who accept that he was. And 63\% want to amend the Constitution to eliminate birthright citizenship, to only $20 \%$ who want to keep things the way they are." Public Policy Polling. “ Trump Supporters Think Obama is A Muslim Born in Another Country," September 01, 2015 at http:// www.publicpolicypolling.com/main/2015/08/ trump-supporters-think-obama-is-a-muslim-born-inanother-country.html (accessed August 3, 2016).

30. Nicholas Confessore and Karen Yourish, "\$2 Billion Worth of Free Media for Donald Trump," 
The New York Times, March 15, 2016 at http://www. nytimes.com/2016/03/16/upshot/measuring-donaldtrumps-mammoth-advantage-in-free-media.html?_r $=0$ (accessed August 6, 2016)and Robert Schroeder , " Trump has gotten nearly $\$ 3$ billion in 'free' advertising." Marketwatch, May 6,2016 athttp://www.marketwatch. $\mathrm{com} /$ story/trump-has-gotten-nearly-3-billion-in-freeadvertising-2016-05-06 (accessed August 6, 2016).

31. On Trump's business failures, see Note 16 above.

32. At the Republican convention, Trump insisted that "you won't hear any lies here," For documentation of Trump's Big and little lies, see Hank Berrien, "Lyin' Donald: 101 Of Trump's Greatest Lies," Dailywire, April 11, 2016 at http://www.dailywire.com/news/4834/ trumps-101-lies-hank-berrien (accessed August 8, 2016).

33. On Trump's appeal to gun owners, see Daniel Hayes, "Donald Trump Takes Aim," The New York Times, August 20, 2016 at http://www.nytimes. com/2016/08/21/opinion/campaign-stops/donaldtrump-takes-aim.html?_r=0 (accessed August 24, 2016).

34. In an article subtitled "How the Christian right came to support a thrice-married adulterer," see Daniel K. Williams "Why Values Voters Value Donald Trump," The New York Times, August 20, 2016 at http:// www.nytimes.com/2016/08/21/opinion/sunday/ why-values-voters-value-donald-trump.html (accessed August 24, 2016).

35. Evan Osmos "The Fearful and the Frustrated: Donald Trump's nationalist coalition takes shape - for now" The New Yorker, August 31, 2015 at http://www. newyorker.com/magazine/2015/08/31/the-fearfuland-the-frustrated (accessed July 22, 2016).

36. Osmos, op. cit.

37. On Fromm and "authoritarian idolatry," see Fromm, 1955 , p. $237 \mathrm{f}$.

38. See Jackson Katz, Man Enough? Donald Trump,
Hillary C, and the Politics of Presidential Masculinity . Northampton, Mass.: Interlink Publishing Company, 2016.

39. See the video at CNN, http://www.cnn.com/ videos/tv/2015/11/26/donald-trump-mocksreporter-with-disability-berman-sot-ac.cnn (accessed August 9, 2016).

40. In a classic example of Freudian projection, over the weekend of August 6-7, Trump accused Hillary Clinton of being unbalanced, coming unhinged, and being mentally unstable, previously the charges being deployed against Trump which I discuss below using Fromm's categories. See Jose A. DelReal, "Trump, in series of scathing personal attacks, questions Clinton's mental health," Washington Post, Aug. 7, 2016 at https://www.washingtonpost.com/news/postpolitics/wp/2016/08/06/trump-in-series-of-scathingpersonal-attacks-questions-clintons-mental-health/ (accessed August 10, 2016). In a speech in West Bend, Wisconsin, on August 16, 2016, Trump called Clinton a "bigot," a charge frequently tossed at him.

41. Maggie Haberman, "Donald Trump Retweets Post With Quote From Mussolini ," The New York Times, February 28, 2106 at http://www.nytimes. com/politics/first-draft/2016/02/28/donald-trumpretweets-post-likening-him-to-mussolini/ (accessed August 8, 2016).

42. Media Matters S taff, "Ted Koppel Compares Donald Trump To Benito Mussolini. Koppel: Trump And Mussolini Both 'Say Very Little In Terms Of Substance, But The Manner In Which They Say It Gets The Crowds Excited," Media Matters, December 16, 2015 at http://mediamatters.org/video/2015/12/16/ ted-koppel-compares-donald-trump-to-benitomuss/207564 (accessed August 9, 2016).

43. For my take on celebrity politics and the implosion of entertainment and politics in U.S. society, see Kellner, in Marshall and Redmond, op.cit, pp.114-134.

\section{References}

Agger, B.(1989) Fast Capitalism. Champaign-Urbana: University of Illinois Press.

Agger, B. (2015) Speeding Up Fast Capitalism. New York and London: Routledge.

Barrett, W. (2016) Trump: The Greatest Show on Earth: The Deals, the Downfall, the Reinvention . New York: Regan Books

Blair, G. 2000. The Trumps. New York: Simon and Schuster.
Burston, D. (1991) The Legacy of Erich Fromm. Cambridge, Mass: Harvard University Press.

Cannon, L. (1982)Reagan. New York: Putnam.

D’Antonio, M. (2015) Never Enough. Donald Trump and the Pursuit of Success . New York: Thomas Dunne Books.

Friedman, L.J. (2013) The Lives of Erich Fromm: Love's Prophet. New York: Columbia University Press. 
Fromm, E.(1991 [1941]). Escape from Freedom. New York: Holt.

Fromm, E.(1955). The Sane Society. New York: Holt s.

Funk, R. (2003) Erich Fromm: His Life and Ideas. Translators Ian Portman, Manuela Kunkel . New York: Continuum International Publishing Group.

Katz J. (2016), Man Enough? Donald Trump, Hillary C, and the Politics of Presidential Masculinity . Northampton, Mass.: Interlink Publishing Company.

Kellner, D. (2017) The American Horror Show: Election 2016 and the Ascendency of Donald J. Trump . Rotterdam, The Netherlands: Sense Publishers.

Kellner, D. (2016) American Nightmare: Donald Trump, Media Spectacle, and Authoritarian Populism . Rotterdam, The Netherlands: Sense Publishers.

Kellner, D. (2012) Media Spectacle and Insurrection, 2011: From the Arab Uprisings to Occupy Everywhere. London and New York: Continuum/Bloomsbury.

Kellner, D. (2005) Media Spectacle and the Crisis of Democracy . Boulder, Col.: Paradigm Press.

Kellner, D. (2003a) From September 11 to Terror War: The Dangers of the Bush Legacy . Lanham, Md.: Rowman and Littlefield.

Kellner, D. (2003b) Media Spectacle . London and New York: Routledge.

Kellner, D. (2001) Grand Theft 2000. Media Spectacle and a Stolen Election . Lanham, Md.: Rowman and Littlefield.

Kranish, M and Marc Fisher (2016) Trump Revealed. An American Journey of Ambition, Ego, Money and Power . New York: Scribner.
Marshall, P.D. and Sean Redmond (2015) A Companion to Celebrity, Malden, MA. and Oxford, UK. Wiley-Blackwell.

Nance,M. (2016) The Plot to Hack America. How Putin's Cyberspies and WikiLeaks Tried to Steal the 2016 Election . New York: Skyhorse Publishing.

O'Brien, T.L. (2016 [2005]). TrumpNation: The Art of Being the Donald. New York: Grand Central Publishing,

O'Donnell, J. and James Rutherford (1991) Trumped!: The Inside Story of the Real Donald Trump-His Cunning Rise and Spectacular Fall. New York: Simon and Schuster.

Trump, Donald J with Tony Schwartz (, 2005 [1987]), The Art of the Deal, New York: Ballantine Books.

Pogash, C. Ed. (2016) Quotations From Chairman Trump . New York: Rosetta Books.

Veblen, T. (1994 [1899]) Theory of the Leisure Class: An Economic Study in the Evolution of Institutions . New York: Dover,.

Wheeler, M (2013) Celebrity Politics. Cambridge, UK. 
